\title{
THE MODERN CORPORATION AND THE ANTITRUST LAWS: FROM TRUST TO DISTRUST
}

\begin{abstract}
JERROLD G. VAN CISE*
C ONGRESS IN 1890 enacted legislation ${ }^{1}$ intended to ensure for this nation a competitive economy. Thereafter it proceeded from time to time to enact supplemental legislation ${ }^{2}$ paying at least lip service $^{3}$ to this objective. The resulting statutes, popularly termed "antitrust laws," in most instances stated in general language the controlling legal principles, and in substance thereby added to the other duties of our judiciary the administrative task of applying those principles to our complex industrial society.
\end{abstract}

The courts by the early 1900's, in administering these antitrust laws, succeeded in formulating from the common law heritage of this legislation a rule of reason ${ }^{5}$-flexible, realistic and commendably practical. The judiciary properly shrank from forcing all industry to fit precisely into any rigid, unvarying procrustean bed. Subsequently, as new antitrust laws were enacted, such as the Clayton Act, this rule of reason was at least for a while extended to apply to these new statutory commands. ${ }^{6}$ The courts in this manner considered the abstract legislative generalities of Congress and one by one effectively breathed life into them, and "it was good."

The most perfect creations of man, however, whether in the form of a constitution, a statute or an automobile, must still be administered by

* Member of the New York Bar.

1 Sherman Act, 26 Stat. 209 (1890), 15 U.S.C.A. $\$ 1$ (1951).

${ }^{2}$ See, e.g., 28 Stat. 509 (1894), as amended, 15 U.S.C.A. $\$ 8$ (1951) (Wilson Tariff Act); 38 Stat. 730 (1914), as amended, 15 U.S.C.A. $\$ 12$ (1951) (Clayton Act); 38 Stat. 717 (1914), as amended, 15 U.S.C.A. $\$ 41$ (1951) (Federal Trade Commission Act).

${ }^{3}$ There is some dispute as to whether a competitive objective was sought after in such subsequent legislation as the Miller-Tydings Act, 50 Stat. 693 (1937), as amended, 15 U.S.C.A. $\$ 1$ (1951) and the Robinson-Patman Act, 49 Stat. 1526 (1936), as amended, 15 U.S.C.A. $\S 13(1951)$.

4 The Congressional definition of "antitrust laws" excludes from this term legislation such as the Federal Trade Commission Act. See 38 Stat. 730 (1914), 15 U.S.C.A. \$ 12 (1951).

${ }^{5}$ Standard Oil Co. v. United States, 221 U.S. 1 (1911); United States v. American Tobacco Co, 221 U.S. 106 (1911); United States v. Addyston Pipe \& Steel Co., 85 Fed. 271 (C.A. 6th, 1898), aff'd, 175 U.S. 211 (1899).

${ }^{6}$ Int'l Shoe Co. v. FTC, 280 U.S. 291, 298 (1930); Standard Oil Co. v. FTC, 282 Fed. 81, 86, 87 (C.A. 3d, 1922), aff'd, 261 U.S. 463 (1923). 
man; which is to say that they must inevitably reflect the frailties of their mortal creators. The antitrust laws, accordingly, in their impact upon industry, necessarily thereafter proceeded to reflect over the succeeding years the current beliefs and disbeliefs of their judicial administrators. The business community by degrees came to learn, to its dismay, that the legislative rules of competition were much like the laws of the Medes and Persians-they altered not in form but varied greatly in application when Cyrus was succeeded by Darius.

Today, these truths should be self-evident to all who advise or participate in industry: Congress by its antitrust enactments merely proposes; it is the Supreme Court which disposes. Depending upon the personnel of our courts, the corporate virtues of yesterday may be business risks today and a criminal offense ${ }^{7}$ tomorrow. Corporate management which solely looks for guidance from past antitrust rulings invites painful disillusionment in the future. He who runs even briefly over the course taken by our antitrust laws can readily read these truths and arrive at these conclusions. "Let us look at the record."

\section{The Old FaIth}

The judicial administrators of our antitrust laws, in the days of our fathers, were ardent converts to a great and abiding faith, namely, faith in business. An initial decade of trial and error in construing these laws had persuaded our courts that he governs best who governs industry least.

Our nation in those years was experiencing an unparalleled industrial growth. The tremendous contributions of business initiative in building up our ever-expanding economy were physically present on all sides. It behooved the public, the prosecutor, and even the courts, to walk humbly in the presence of the nation's benefactors. The decisions of yesterday abounded, accordingly, with repeated reaffirmations of this profound faith of our fathers in business and in businessmen.

On the one hand, business was assured by our courts that it was entitled to substantial freedom of action in making its competitive decisions:

Effective competition requires that traders have large freedom of action when conducting their own affairs. Success alone does not show reprehensible methods, although it may increase or render insuperable the difficulties which rivals must face. ${ }^{8}$

True, the courts realized, competition might be restrained by business, if given such freedom of action; but, after all, restraint was inevitable in any form of commercial transaction:

' See, e.g., United States v. South-Eastern Underwriters Ass'n, 322 U.S. 533 (1944).

8 FTC v. Curtis Pub. Co., 260 U.S. 568, 582 (1923). 
But the legality of an agreement or regulation cannot be determined by so simple a test, as whether it restrains competition. Every agreement concerning trade, every regulation of trade, restrains. To bind, to restrain, is of their very essence. ${ }^{9}$

Business was even assured great freedom in entering into agreements with competitors:

The restrictions the Act imposes are not mechanical or artificial ... they do not seek to establish a mere delusive liberty either by making impossible the normal and fair expansion of that commerce or the adoption of reasonable measures to protect it from injurious and destructive practices and to promote competition upon a sound basis.... Realities must dominate the judgment. The mere fact that the parties to an agreement eliminate competition between themselves is not enough to condemn it. ${ }^{10}$

On the other hand, governmental agencies such as the Federal Trade Commission were sternly warned by the courts to refrain from amateurish administrative interference with commercial matters:

The powers of the Commission are limited by the statutes. It has no general authority to compel competitors to a common level, to interfere with ordinary business methods or to prescribe arbitrary standards for those engaged in the conflict for advantage called competition.... [I]t is essential that those who adventure their time, skill and capital should have large freedom of action in the conduct of their own affairs. ${ }^{11}$

Federal Trade Commissioners were warned that their functions were strictly limited to the tracking down of predatory and monopolistic practices:

It was never intended by Congress that the Trade Commission would have the duty and power to judge what is too fast a pace for merchants to proceed in business and to compel them to slow up. To do so would be to destroy all competition except that which is easy. ${ }^{12}$

Even governmental investigators of industry were required to proceed modestly and with an appropriate appreciation of the deference due to business:

Anyone who respects the spirit as well as the letter of the Fourth Amendment would be loath to believe that Congress intended to authorize one of its subordinate agencies to sweep all our traditions into the fire ... and to direct fishing expeditions into private papers on the possibility that they may disclose evidence of crime..$^{13}$

Above all, the courts in administering our antitrust laws insisted that where businessmen were on trial they were to be regarded as innocent until clear evidence to the contrary was produced. Thus a mere showing

- Board of Trade of Chicago v. United States, 246 U.S. 231, 238 (1918).

${ }^{10}$ Appalachian Coals, Inc. v. United States, 288 U.S. 344, 360 (1933).

${ }^{11}$ FTC v. Sinclair Refining Co., 261 U.S. 463, 475-76 (1923).

12 National Biscuit Co. v. FTC, 299 Fed. 733, 739 (C.A. 2d, 1924).

${ }^{13}$ FTC v. American Tobacco Co., 264 U.S. 298, 305-306 (1924). 
that competitors in an industry tended to follow the price changes of one of their number was considered to prove little or nothing:

And the fact that competitors may see proper, in the exercise of their own judgment, to follow the prices of another manufacturer, does not establish any suppression of competition or show any sinister domination. ${ }^{14}$

The realistic observation was made that:

Grocers, butchers, and all other lines in the same markets generally sell the same things at the same prices, for the sound reasons that they wish to get all they can, that they cannot get more than the price at which the bulk of what is sold in their respective markets is selling, and that they do not think it wise to cut prices. ${ }^{15}$.

Governmental efforts to win litigation, not by unequivocal evidence but on the basis of circumstantial deductions made by expert witnesses from general industrial data, were scathingly denounced:

It has become an aphorism that there is danger of deception in generalities, and in a case of this importance we should have something surer for judgment than speculation, something more than a deduction equivocal of itself even though the facts it rests on or asserts were not contradicted. If the phenomena of production and prices were as easily resolved as the witness implied, much discussion and much literature have been wasted, and some of the problems that are now distracting the world would be given composing solution. ${ }^{16}$

\section{The OLD RULES}

A corporation in the days of our fathers, by reason of this judicial deference to business, was relatively untroubled by the antitrust laws. It was free to act on the assumption that what it did would be considered to be mere good, clean fun so long as it abstained from conduct of the nature proscribed by the pulpit. If it roughed up a competitor, it was able to count on receiving no more than a judicial reprimand, with an understanding aside that boys would be boys. This golden age of faith in business indeed reached a point where judicial trust in effect endorsed industrial trusts. Combinations of as much as seventy and eighty percent of an industry were said to be unobjectionable. ${ }^{17}$ Whatever was, in industry, was right.

Corporate management, to the slight degree it bothered to consider the antitrust laws at all, found the then current rules of the competitive game to be roughly as follows:

14 United States v. International Harvester Co., 274 U.S. 693, 708-709 (1927).

1s United States v. Standard Oil Co. (N.J.), 47 F. 2d 288, 316-17 (E.D. Mo., 1931)

16 United States v. U.S. Steel Corp., 251 U.S. 417, 448-49 (1920).

17 United States v. Winslow, 227 U.S. 202 (1913); United States v. United Shoe Machinery Co., 247 U.S. 32 (1918); United States v. Quaker Oats Co., 232 Fed. 499 (N.D. Ill., 1916), appeal dismissed, 253 U.S. 499 (1920). 
Selection of customers. The corporation, if acting independently of others, might deal or not deal with whom it pleased. Thus it could refuse to sell to price cutters..$^{18}$ It might decline to buy from one who sold to competitors. ${ }^{19}$ The government had no right to select its business customers. ${ }^{20}$ The law was clear:

It is the right, "long-recognized," of a trader engaged in an entirely private business, "freely to exercise his own independent discretion as to parties with whom he will deal." 21

Quotation of prices. The corporation enjoyed wide latitude in its pricing. It might follow the prices of a competitor, ${ }^{22}$ utilize industry basing points ${ }^{23}$ and sell at any level it pleased-even below cost. ${ }^{24}$ One court summarized the law as follows:

It is settled law that a trader or manufacturer engaged in private business, not of a public or quasi public character, may sell to whom he pleases, may charge different prices for the same article to different individuals, and may make such discrimination in his business as he chooses. ${ }^{25}$

Method of distribution. In the absence of monopolization, a businessman might individually select any of the customary channels and forms for distributing goods. He could sell to independent merchants, require exclusive dealing of them, ${ }^{26}$ and promise in return to sell only to one in any area. ${ }^{27}$ On the other hand, he might sell only through agents. ${ }^{28}$ Even certain restrictions on use and resale were permissible. ${ }^{29}$ It was said of the Sherman Act that

${ }^{18}$ United States v. Colgate \& Co., 250 U.S. 300 (1919).

${ }^{19}$ FTC v. Raymond Bros. Clark Co., 263 U.S. 565 (1924).

${ }^{20}$ Great Atlantic \& Pacific Tea Co. v. Cream of Wheat Co., 227 Fed. 46 (C.A. 2d, 1915).

${ }^{21}$ FTC v. Raymond Bros. Clark Co., 263 U.S. 565, 573 (1924).

22 United States v. Int'l Harvester Co., 274 U.S. 693 (1927).

${ }^{23}$ Cement Mfrs. Protective Ass'n v. United States, 268 U.S. 588 (1925).

${ }^{24}$ Sears, Roebuck \& Co.v. FTC, 258 Fed. 307 (C.A. 7th, 1919).

${ }^{25}$ Fosburgh v. Calif. \& Hawaiian Sugar Refining Co., 291 Fed. 29, 36 (C.A. 9th, 1923). The right to discriminate was qualified to some degree, of course, by Section 2 of the Clayton Act, 38 Stat. 730 (1914), 15 U.S.C.A. $\$ 13$ (1951), but this statute in its then form caused relatively little trouble.

${ }^{26}$ D. R. Wilder Mfg. Co. v. Corn Products Refining Co., 236 U.S. 165 (1915). The right to require exclusive dealing was also qualified to some extent by Section 3 of the Clayton Act, ibid., at $\S 14$, but only if carried too far.

${ }^{27}$ United States v. Int'I Harvester Co., 274 U.S. 693, 697 (1927); cf. Moore v. N.Y. Cotton Exchange, 270 U.S. 593 (1926).

${ }^{28}$ United States v. General Electric Co., 272 U.S. 476 (1926).

${ }^{29}$ Cement Mfrs. Protective Ass'n v. United States, 268 U.S. 588, 594-97 (1925); P. Lorillard Co. v. Weingarden, 280 Fed. 238 (W.D. N.Y., 1922). 
the statute did not forbid or restrain the power to make normal and usual contracts to further trade by resorting to all normal methods, whether by agreement or otherwise, to accomplish such purpose..$^{30}$

Licensing of patents. The corporate owner of a patent was viewed by the courts as the lawful owner of a monopoly. It was entitled to grant exclusive licenses, ${ }^{31}$ restrict the prices at which its licensees sold, ${ }^{32}$ and, if it so desired, condition the license of one patent upon the acceptance of a license under another. ${ }^{33}$ The essential value of a patent was said to be in its power to restrain:

Of course, there is restraint in a patent. Its strength is in the restraint, the right to exclude others from the use of the invention, absolutely or on the terms the patentee chooses to impose. This strength is the compensation which the law grants for the exercise of invention. Its exertion within the field covered by the patent law is not an offense against the Anti-Trust Act. ${ }^{34}$

Agreements with competitors. The corporation of yesterday was given wide latitude not only to act for itself, but also to engage in joint efforts with competitors to improve trade conditions. In the absence of conduct readily identified as boycott and the like, companies were permitted to exchange statistics, ${ }^{35}$ utilize joint agencies, ${ }^{36}$ fix prices for limited periods, ${ }^{37}$ and in exceptional cases agree upon undisguised industry quotas. ${ }^{38} \mathrm{Busi}$ nessmen were informed that they were better equipped to cure trade evils than the law:

Voluntary action to end abuses and to foster fair competitive opportunities in the public interest may be more effective than legal processes. And cooperative endeavor may appropriately have wider objectives than merely the removal of evils which are infractions of positive law. Nor does the fact that the correction of abuses may tend to stabilize a business, or to produce fairer price levels, require that abuses should go uncorrected. ${ }^{39}$

Foreign commerce. The hardy corporation which had ventured into foreign trade was given practically a free hand in the absence of clear monopolization affecting this country. Joint ownership by American companies of a

${ }^{30}$ United States v. American Tobacco Co., 221 U.S. 106, 179 (1911).

31 Virtue v. Creamery Package Co., 227 U.S. 8 (1913).

32 United States v. General Electric Co., 272 U.S. 476 (1926).

${ }^{33}$ Cf. FTC v. Paramount Famous-Lasky Corp., 57 F. 2d 152 (C.A. 2d, 1932).

${ }^{34}$ United States v. United Shoe Mach. Co., 247 U.S. 32, 57 (1918).

${ }^{35}$ Maple Flooring Mfrs. Ass'n v. United States, 268 U.S. 563 (1925).

${ }^{36}$ Appalachian Coals, Inc. v. United States, 288 U.S. 344 (1933).

${ }^{37}$ Board of Trade of Chicago v. United States, 246 U.S. 231 (1918).

${ }^{38}$ Nat'l Ass'n of Window Glass Mfrs. v. United States, 263 U.S. 403 (1923).

${ }^{39}$ Sugar Inst., Inc. v. United States, 297 U.S. 553, 598 (1936). 
foreign subsidiary was approved; ${ }^{40}$ international patent agreements with territorial restrictions were upheld; ${ }^{41}$ and even outright monopolization was in one instance left undisturbed where the acts of the American company were solely performed abroad. ${ }^{42}$ The courts ruled that our nationals were entitled to use whatever methods were necessary to conduct foreign trade:

To hold otherwise would be, practically and commercially, to enjoin the steel trade of the United States from using the business methods which are necessary in order to build up and maintain a dependable business abroad, and if the Sherman Law were so construed, it would itself be a restraint of trade. ${ }^{43}$

Over-all size. Finally, the corporation of yesterday was assured that there was no limit to the size to which it might lawfully grow, provided it utilized only lawful means in the process. Size was held to be no offense. ${ }^{44}$ Vertical integration was viewed as affirmatively promoting the public interest. ${ }^{45}$ An acquisition of the stock of competitors had to restrain trade substantially before it could be subjected to challenge even under Section 7 of the Clayton Act. ${ }^{46}$ The mutual affection of courts and businessmen was touchingly manifest in rulings such as the following:

- It is said that from seventy to eighty per cent. of all the shoe machinery business was put into a single hand ... taking it as true we can see no greater objection to one corporation manufacturing seventy per cent. of three non-competing groups of patented machines collectively used for making a single product than to three corporations making the same proportion of one group each. The disintegration aimed at by the statute does not extend to reducing all manufacture to isolated units of the lowest degree. $^{47}$

\section{The New FaItH}

Some faiths fall upon ground which permits immediate and rapid growth but which subsequently fails to sustain such faith when subjected

40 United States v. Keystone Watch Case Co., 218 Fed. 502 (E.D.Pa., 1915), appeal dismissed, 257 U.S. 664 (1921).

41 Thoms v. Sutherland, 52 F. 2d 592 (C.A. 3d, 1931).

42 American Banana Co. v. United Fruit Co., 213 U.S. 347 (1909); but cf. United States v. Sisal Sales Corp., 274 U.S. 268 (1927).

43 United States v. U.S. Steel Corp., 223 Fed. 55, 114 (D.C.N.J., 1915), aff'd, 251 U.S. 417 (1920).

44 United States v. Int'l Harvester Co., 274 U.S. 693 (1927); United States v. Quaker Oats Co., 232 Fed. 499 (N.D.Ill, 1916).

45 United States v. U.S. Steel Co., 251 U.S. 417 (1920); Alexander Milburn Co. v. Union Carbide \& Carbon Corp., 15 F. 2d 678 (C.A. 4th, 1926), cert. denied, 273 U.S. 757 (1927).

${ }^{45}$ Int'l Shoe Co. v. FTC, 280 U.S. 291 (1930).

47 United States v. Winslow, 227 U.S. 202, 217 (1913). 
to adversity. The Great Depression came in 1929 to test the apparently deep and abiding faith of the judiciary in business. Investors lost their savings; employees lost their jobs; and businessmen lost their standing of first in the hearts of their countrymen. In their distress, all eyes were raised to Washington.

A new competing faith then was born-the Cult of Washington-to challenge the Cult of Business. The national creed of this new faith was "In Government We Trust." Its missionaries were zealous government office holders eager to spread the new theology to all voters. And this Cult of Washington grew and prospered. The emergency of the depression was succeeded by the emergency of war; this in turn was followed by the crises of the cold war and Korea; and continuous injections of government controls into the blood streams of business over this period became habitforming. The abnormal became the normal order of the day. Government rather than business seemed to perform the miracle of providing food to feed the thousands.

The new faith in government, under these circumstances, won judicial converts as well as much of the general public. Right thinking towards Washington, moreover, became the straight and narrow path to judicial appointment and advancement. In due course, accordingly, the courts commenced to argue that government, rather than business, was the omnipotent repository of superior wisdom to whom all should defer. The FTC, for example, was said to be an agency created by Congress

whose membership would at all times be experienced, so that its conclusions would be the result of an expertness coming from experience.... [C]ourts should not lightly modify the Commission's orders made in efforts to safeguard a competitive economy. ${ }^{48}$

Solicitous precautions were taken by the courts to ensure that government agencies were not handicapped in suing business through any disturbing necessity for proving their case, if there was any reasonable possibility that the governmental experts might be right:

the Commission is authorized by the Act to bar discriminatory prices upon the "reasonable possibility" that different prices for like goods to competing purchasers may have the defined effect on competition.... It would greatly handicap effective enforcement of the Act to require testimony to show that which we believe to be selfevident, namely, that there is a "reasonable possibility" that competition may be adversely affected by a practice under which manufacturers and producers sell their goods to some customers substantially cheaper than they sell like goods to the competitors of these customers. ${ }^{49}$

${ }^{48}$ FTC v. Cement Inst., 333 U.S. 683, 720, 726 (1948).

${ }^{49}$ FTC v. Morton Salt Co., 334 U.S. 37, 47, 50 (1948). 
Facts which heretofore had been viewed by the courts as proving nothing by themselves, such as an identity of price quoted by two competitors, were now viewed as sufficient without more to sustain government charges: a customer located in St. Paul could purchase cans at the same delivered price irrespective of whether the purchase was made from a member located in Chicago or St. Paul. Just how such an unnatural situation could be brought about by members of an industry without a plan or agreement is difficult, if not impossible, to visualize..$^{50}$

The new faith in government inevitably drove from judicial minds their faith in business. The attitude of the courts toward industry commenced to range from disinterested impartiality to pronounced coolness. Trust in a successful large business rapidly turned into undisguised distrust. Its executives would not be believed on the stand if contradicted by writings of the past:

Where such testimony is in conflict with contemporaneous documents we can give it little weight. ${ }^{51}$

Industry's cardinal virtue of private initiative now was pronounced an unlawful method of excluding competition, if exercised successfully:

It [defendant] insists that it never excluded competitors; but we can think of no more effective exclusion than progressively to embrace each new opportunity as it opened, and to face every newcomer with new capacity already geared into a great organization, having the advantage of experience, trade connections and the elite of personnel..$^{52}$

Even minority opinions, when endorsing a conclusion favorable to a defendant company, took care to disavow kindly feelings toward the structure of American industry:

big business has become bigger and bigger. Monopoly has flourished. Cartels have increased their hold on the nation. The trusts wax strong. There is less and less place for the independent. ${ }^{53}$

The effect of this changed approach of the courts towards government and business was most dramatically reflected in judicial rulings which more and more curtailed the rights of business to defend itself when on trial. Industry was no longer permitted to show that trade practices under attack had had little restraining effect upon competition if the volume of business involved was not insignificant:

it is unreasonable, per se, to foreclose competitors from any substantial market... The volume of business affected by these contracts cannot be said to be insignificant or insubstantial. .4

${ }^{50}$ Milk and Ice Cream Can Inst. v. FTC, 152 F. 2d 478, 481 (C.A. 7th, 1946).

51 United States v. U.S. Gypsum Co., 333 U.S. 364, 396 (1948).

52 United States v. Aluminum Co., 148 F. 2d 416, 431 (C.A. 2d, 1945).

${ }^{63}$ Standard Oil Co. (Calif.) v. United States, 337 U.S. 293, 315 (1949).

${ }^{54}$ Int'l Salt Co. v. United States, 332 U.S. 392, 396 (1947). 
Nor was business allowed to prove that trade practices were adopted for the purpose and with the effect of safeguarding industry from uneconomic and tortuous practices:

even if copying were an acknowledged tort under the law of every state, that situation would not justify petitioners in combining together to regulate and restrain interstate commerce in violation of federal law..5

Indeed, conspiracy charges brought against industrial defendants came to be sustained by such inadequate proof as to call forth the comment in a dissenting opinion in a non-antitrust case that

a conspiracy often is proved by evidence that is admissible only upon assumption that conspiracy existed..$^{56}$

\section{THE NEW RULES}

The corporation of today, by reason of this change in the courts from an attitude of trust to one at times approaching distrust, can no longer be indifferent to the antitrust laws. Failure to be alive to those laws may be penalized by divestiture of the right to live under those laws. One by one the old rules of competition are being subjected to judicial scrutiny, and many after trial are being found wanting. There is nothing so stale as yesterday's opinion in many phases of antitrust law. Our Supreme Court at times seems to pattern its approach to old antitrust opinions much like Mark Twain's New England weather. If you don't like it, wait a minute.

Corporate management, under these circumstances, can be sure of nothing. A principle of law may be here today and gone tomorrow. Many of the old rules are still valid-but which ones, that is the question. Under these circumstances the writer has elsewhere advised eight rough rules of thumb for dealing on a strictly day to day basis with industry's problems. ${ }^{57} \mathrm{As}$ of the date of this paper, the following changes in the old principles of competition seem to have occurred:

Selection of customers. A corporation, even if acting independently of others, in some limited areas has no longer any unqualified right to deal or not to deal with others. A corporation selling through two subsidiaries has been denied the right to refuse to sell to a customer who flouted its request to hold prices down. ${ }^{58} \mathrm{~A}$ manufacturer of a unique linen rug has been condemned for cutting off a dealer who sold to a direct customer of the manu-

${ }^{65}$ Fashion Originators' Guild of America, Inc. v. FTC, 312 U.S. 457, 468 (1941).

${ }^{58}$ Krulewitch v. United States, 336 U.S. 440, 453 (1949).

57 See Van Cise, The Antitrust Laws from the Point of View of a Private Practitioner (Practising Law Inst. Monog., 1949).

${ }^{68}$ Kiefer-Stewart Co. v. Seagram \& Sons, Inc., 340 U.S. 211 (1951). 
facturer. ${ }^{59} \mathrm{~A}$ news agency found neither to monopolize nor to dominate has been required to serve competitors of its subscribing members. ${ }^{60}$ How far the right of a seller to select his customers has now been qualified by the courts is not known; but it is significant that a company doing a small percentage of the available business of an industry was recently held to be "boycotting" where it sought to deal only with those quoting better prices to it than to its competitors.

When A\&P did not get the preferential discount or allowance it demanded, it did not simply exercise its right to refuse to contract with the supplier. It went further and served notice on the supplier that if that supplier did not meet the price dictated by A\&P, not only would the supplier lose the business at the moment under negotiation, but it would be put upon the unsatisfactory list or private blacklist of A\&P and could expect no more business from the latter. This was a boycott and in and of itself is a violation of the Sherman Act. ${ }^{61}$

Quotation of prices. A corporation can be sure today of only one rule in pricing, namely, that whatever it does will entail risks. If it quotes the same price as its competitors, it will be in danger of a charge of conspiracy. ${ }^{62}$ If it quotes this same price generally, as it must in a competitive market, but varies it in specific instances in order to get new business and prove the absence of conspiracy, it will face a charge of discrimination. ${ }^{63}$ It will find two recent decisions denying that all basing point pricing is unlawful, ${ }^{64}$ and a still later opinion by the same Court ruling that

the combined effect of the two cases was to forbid the adoption for sales purposes of any basing point price system. ${ }^{65}$

Methods of distribution. A modern corporation must today exercise great care in determining how to distribute its goods. It may invite trouble if it sells its products to retailers who agree to deal exclusively in its products. ${ }^{66}$ If it sells directly to consumers through agents ${ }^{67}$ or vertically-integrated

69 United States v. Klearflax Linen Looms, Inc., 63 F. Supp. 32 (D.C. Minn., 1945).

${ }^{60}$ Associated Press v. United States, 326 U.S. 1 (1945); also cf. Lorain Journal Co. v. United States, 72 S.Ct. 181 (1951).

61 United States v. N.Y. Great Atlantic \& Pacific Tea Co., 173 F. 2d 79, 87 (C.A. 7th, 1949).

62 Triangle Conduit \& Cable Co. v. FTC, 168 F. 2d 175 (C.A. 7th, 1948), aff'd sub nom. Clayton Mark \& Co. v. FTC, 336 U.S. 956 (1949).

s3 Standard Oil Co. v. FTC, 340 U.S. 231 (1951).

64 FTC v. A. E. Staley Mfg. Co., 324 U.S. 746 (1945); Corn Products Co.v. FTC, 324 U.S. 726 (1945).

${ }^{65}$ FTC v. Cement Inst., 333 U.S. 683, 723 (1948).

$\infty$ Standard Oil Co. (Calif.) v. United States, 337 U.S. 293 (1949).

67 United States v. Masonite Corp., 316 U.S. 265 (1942). 
outlets, ${ }^{68}$ it must keep in mind new rulings qualifying its freedom to do so. Moreover, new law may be in the making that its terms to its customers, even when not pricing terms, must in some instance be uniform, on the theory that:

Each discriminatory contract constituted a conspiracy ${ }^{69}$

Licensing of patents. The corporate owner of a patent in particular is currently bothered and bewildered. The courts now seldom talk of a patentee's right to which the public faith is pledged. ${ }^{70}$. The patentee instead is said to have a privilege conditioned by a public purpose. ${ }^{71}$ He may safely own and license rights under large groups of patents if he licenses all on substantially nondiscriminatory terms, ${ }^{72}$ but he should avoid imposing price $^{73}$ and comparable restraints ${ }^{74}$ upon its licensees. How many former rights a patentee retains is a secret known, if at all, only to Washington. This alone can safely be asserted: few judicial tears are being shed over the practical problems of a licensor in figuring out a lawful way to obtain a reasonable return on his patented invention:

It is without significance that, as petitioner contends, it is not practicable to exploit the patent rights by granting licenses. ${ }^{75}$

Agreements with competitors. The corporation of today is not yet debarred from all intercourse with its competitors. Once it starts to cross over to its competitor's side of the street, however, it finds the safety zone to be exceedingly narrow and well policed. Trade associations are viewed with disfavor, to the extent that the Supreme Court on its own motion has ordered dissolved a trade association appealing to it for relief. ${ }^{66}$ Trade evils apparently may now be corrected only by government if they affect prices ${ }^{77}$ or involve disciplinary measures. ${ }^{78}$ Even simultaneous identity of action on nonprice matters by competitors is questioned..$^{79}$ Business and labor are equally suspect in this phase of the law:

\footnotetext{
${ }^{68}$ United States v. N.Y. Great Atlantic \& Pacific Co., 173 F. 2d 79 (C.A. 7th, 1949).

69 United States v. Paramount Pictures, 334 U.S. 131, 160 (1948).

${ }^{70}$ Joseph Grant v. E. \& H. Raymond, 6 Pet. (U.S.) 218, 242 (1832).

${ }^{71}$ Mercoid Corp. v. Mid-Continent Co., 320 U.S. 661, 666 (1944).

72 Automatic Radio Co. v. Hazeltine, 339 U.S. 827 (1950).

${ }^{73}$ United States v. Line Material Co., 333 U.S. 287 (1948).

${ }^{44}$ United States v. U.S. Gypsum Co., 333 U.S. 364 (1948).

${ }^{75}$ B. B. Chemical Co. v. Ellis, 314 U.S. 495, 498 (1942).

${ }^{76}$ Hartford-Empire Co. v. United States, 323 U.S. 386 (1945).

77 United States v. Socony-Vacuum Oil Co., 310 U.S. 150 (1940).

${ }^{78}$ Fashion Originators' Guild of America, Inc. v. FTC, 312 U.S. 457 (1941).

${ }^{79}$ Interstate Circuit v. United States, 306 U.S. 208 (1939).
} 
violations of antitrust laws could not be defended on the ground that a particular accused combination would not injure but would actually help manufacturers, laborers, retailers, consumers, or the public in general. ${ }^{80}$

Foreign commerce. The corporation that ventures beyond our shores, instead of being given every encouragement from home, now is able to count on being shot at from both sides of the water. If it licenses patents and trade marks, it may not even agree to the territorial covenants required by trade mark law. ${ }^{81}$ If it is forced to make a deal with a cartel as the price of being able to do export business, it must abstain and withdraw from business. ${ }^{82}$ Agreements per se unlawful in interstate commerce have been said to be equally unlawful in foreign commerce. ${ }^{83}$ Congress proposed in its Webb Act to give exporters greater freedom abroad, but the courts have summarily disposed of much of this illusory freedom. ${ }^{84}$ When defendants have pointed out that commodities cannot readily be exported today, making necessary foreign investments in lieu thereof, the answer has been given that the antitrust laws and the courts know better:

This position ignores the fact that the provisions in the Sherman Act against restraints of foreign trade are based on the assumption, and reflect the policy, that export and import trade in commodities is both possible and desirable. ${ }^{85}$

Over-all size. Finally, the corporation of today is discouraged in every possible way from expanding its activities. Size is now castigated as an earmark of monopoly power. ${ }^{86}$ Growth through acquisition, ${ }^{87}$ the leverage of vertical ${ }^{88}$ or horizontal ${ }^{89}$ integration, or even foresighted initiative ${ }^{90}$ can in some situations be unlawful. Business size of sufficient magnitude to represent power to exclude competitors from the market is termed monopoly power. ${ }^{91}$ At all times a sincere and zealous minority of the Supreme Court

${ }^{80}$ Giboney v. Empire Storage and Ice Co., 336 U.S. 490, 496 (1949).

81 Timken Roller Bearing Co. v. United States, 341 U.S. 593 (1951).

82 United States v. Nat'l Lead Co., 332 U.S. 319 (1947).

${ }^{83}$ United States v. Imperial Chemical Industries, 100 F. Supp. 504 (S.D.N.Y. 1951).

84 United States v. Minnesota Mining \& Mfg. Co., 92 F. Supp. 947 (D.C. Mass., 1950); United States v. U.S. Alkali Export Ass'n, 86 F.Supp. 59 (S.D.N.Y., 1949).

${ }^{85}$ Timken Roller Bearing Co. v. United States, 341 U.S. 593, 597 (1951).

${ }^{86}$ United States v. Paramount Pictures, 334 U.S. 131 (1948).

${ }^{87}$ See the provisions of the amended Section 7 of the Clayton Act, 38 Stat. 717 (1914), as amended, 15 U.S.C.A. $\$ 18$ (1951).

88 United States v. Yellow Cab Co., 332 U.S. 218 (1947).

${ }^{89}$ United States v. Griffith, 334 U.S. 100 (1948).

${ }^{90}$ United States v. Aluminum Co., 148 F. 2d 416 (C.A. 2d, 1945).

${ }^{91}$ American Tobacco Co. v. United States, 328 U.S. 781 (1946). 
appears to approach business problems with the objective of ensuring that power alone resides with the government. Nowhere has this firmly held objective been more candidly outlined than in the following extract from a recent famous dissenting opinion:

Industrial power should be decentralized. It should be scattered into many hands so that the fortunes of the people will not be dependent on the whim or caprice, the political prejudices, the emotional stability of a few self-appointed men. The fact that they are not vicious men but respectable and social minded is irrelevant. That is the philosophy and the command of the Sherman Act. It is founded on a theory of hostility to the concentration in private hands of power so great that only a government of the people should have it.92

\section{The FUTURe RULes}

The true shape of things to come has not, of course, as yet emerged. The future seldom reveals itself with precise clarity to the present. The general pattern of tomorrow's rules for business being currently developed under the influence of the Cult of Washington, however, is all too apparent from the above analysis.

The underlying premise of these new rules for business is one of distrust towards industry. Businessmen are believed continuously to be conspiring to build industrial structures giving to their owners powers which should be held only by government, much as the plainsmen of ancient times sought to erect a high tower reaching unto heavenly mansions reserved to the gods. The first commandment of at least a minority of our judiciary, accordingly, is that such industrial structures should, like the tower of Shinar, be destroyed, and their builders scattered. ${ }^{93}$

The other new rules for business currently being developed face up to those situations wherein for some reason a Babelonian destruction of industrial structures would be impractical or impolitic. In such cases it is reluctantly concluded that these industrial structures may be retained in form, but it is carefully provided that they must be so subjected to regulation as to effectively destroy their powers in substance. Business should deal not with those with whom it wishes to deal but with those with whom the government wishes it to deal. ${ }^{94}$ It should buy, sell and license on a nondiscriminatory, nonrestrictive basis. ${ }^{95}$ Aggressive solicitation of new

92 United States v. Columbia Steel Co., 334 U.S. 495, 536 (1948), rehearing denied, 334 U.S. 862 (1948).

${ }^{93}$ Ibid.

9s See "Selection of customers," supra at 677.

${ }^{95}$ See "Quotation of prices," "Methods of distribution" and "Licensing of patents," supra at $678-79$. 
business opportunities should be barred if the company is unduly successful; instead industry should wait for business to be thrust upon it. ${ }^{96} \mathrm{Fi}$ nally, self-regulation of industry should be so completely proscribed as to make government regulation alone the vehicle for eliminating trade evils. ${ }^{97}$ In short, these supplemental rules for competition would seem to be patterned upon the rules of industry where business is the barely tolerated ward of the government and competition is superseded with regulation, namely, the public utility.

This developing pattern of ruin or rule of business, needless to say, is foreign to our previous antitrust traditions. The antitrust laws, unlike the Koran, have not heretofore been thought to authorize a grim Islamic choice to business of either being cut into small helpless pieces or of submitting to the rule of the true believers. Senator Sherman presumably would have been surprised, and possibly annoyed, had anyone accused him in 1890 of sponsoring legislation to give to government any such sweeping powers of life, death and regulation over private business. Certainly the use of our antitrust laws to justify imposing public utility regulation upon private industry is novel.

Towards public businesses the approach is regimentation. With their accepted inherent characteristics of "monopoly," the public imposes obligations of affirmative action upon those who engage in such "public" businesses. They must serve all, with adequate facilities, without discrimination, at a reasonable price and for so long as the public needs their service. This the public more and more backs up with a meticulous regimentation of their conduct by regulatory bodies so as to get from these businesses what it feels it requires. In turn the public confers on these businesses certain correlative rights and security.

On the other hand, to the "private" businesses the fundamental approach is "freedom." We expect to get from them the benefit of increasing productivity and consequently the possibility of a rising general standard of living and results in the production and exchange of products and services of a character and on terms ordinarily reasonably satisfactory to both buyer and seller. We expect these results ordinarily to flow reasonably automatically from the play of initiative and dynamic urge of selfinterest in both buyer and seller and the spur and rein of competitive influences on the minds of both. We know this free play in "private" businesses involves inevitable wastes and duplication of efforts and facilities. We know it will never work perfectly. There will often be inefficiencies, losses and hardships. But we are disposed to take all this as part of the price we are prepared to pay for freedom and its dynamic urges..$^{98}$

${ }^{96}$ See "Over-all size," supra at 680.

${ }^{97}$ See "Agreements with competitors," supra at 679.

${ }_{98}$ Letter of Transmittal and Memorandum for the President's Committee on Business and Government Relations, Submitted by a Special Committee of the Section on Anti-Trust Law of the New York State Bar Association (1950), pp. i-ii. 
It is possible, of course, that the courts may eventually recoil from the extremes to which the Cult of Washington is currently taking them. This developing pattern of the sword or the yoke for industry is not as yet the law of the land, and we may still hope that it may never be. On the one hand, there have been recent indications that faith in business is not completely dead, even in judicial circles. Small may be the regard of many towards industry, but there are still some who profess to love it. On the other hand, faith in government is currently being reappraised downward by many as the result of disillusioning developments at home and abroad. The discovery may eventually be made that trust in business is not necessarily inconsistent with trust in government, that each with its virtues and failings is essential in a free, competitive society, and that rules compatible with the interests of business and government are both possible and desirable. Why either business or government should claim infallibility is a mystery understood only by its devotees, as each in the last analysis is merely a corporate fiction describing an aggregation of fallible human beings. 